\title{
1 Hepatitis B virus infection in the Lao PDR: A systematic 2 review
}

3

4 Authors

5 Lisa Hefele ${ }^{1}$, Phonethipsavanh Nouanthong ${ }^{2}$, Judith M. Hübschen ${ }^{1}$, Claude P Muller ${ }^{1}$,

6 Antony P Black ${ }^{2 *}$

7

$8{ }^{1}$ Department of Infection and Immunity, Luxembourg Institute of Health, Esch-sur-Alzette,

9 Grand-Duchy of Luxembourg

10 2Lao-Lux Laboratory, Institut Pasteur du Laos, Ban Kao-Gnot, Sisattanak district, Vientiane,

11 Lao PDR

12

$13 \quad$ *Corresponding author: A. Black; a.black@pasteur.la

16 Article Type: Review

17 Keywords: Hepatitis B, Public Health, Epidemiology

18 Short title: Hepatitis B in the Lao PDR 
medRxiv preprint doi: https://doi.org/10.1101/2022.01.23.21265872; this version posted January $25,2022$. The copyright holder for this preprint (which was not certified by peer review) is the author/funder, who has granted medRxiv a license to display the preprint in It is made available under a CC-BY-NC-ND 4.0 International license.

\section{Abbreviations}

20 anti-HBs = Anti-hepatitis B surface antigen antibodies;

21 anti-HBc $=$ Anti-hepatitis $\mathrm{B}$ core antigen antibodies;

22 DTPw-HepB-Hib = Diphtheria, tetanus, pertussis, hepatitis B and Haemophilus influenzae

23 type b vaccine;

24 HBsAg = Hepatitis B surface antigen;

$25 \mathrm{HBV}=$ Hepatitis B virus;

26 MTCT $=$ Mother-to-child transmission 
medRxiv preprint doi: https://doi.org/10.1101/2022.01.23.21265872; this version posted January $25,2022$. The copyright holder for this preprint (which was not certified by peer review) is the author/funder, who has granted medRxiv a license to display the preprint in It is made available under a CC-BY-NC-ND 4.0 International license.

\section{Abstract}

28 Introduction

29 Even though hepatitis B is endemic in the Lao PDR, the understanding of the epidemiology of

30 hepatitis B infection is incomplete. This article reviews the available literature about hepatitis

31 B seroprevalence, risk factors and genotypes in the Lao population in order to provide an up32 to date summary of the HBV epidemiology in the Lao PDR, identify knowledge gaps and 33 provide public health recommendations.

34 Methods

Using PubMed/Medline and ScienceDirect, all studies reporting the prevalence of hepatitis B markers or genotype distribution in the Lao PDR published were systematically reviewed.

$37 \quad$ Results

The 21 studies included focused on the general population, blood donors, women, children, 39 health care workers and garment factory workers. The studies varied extensively in sample size, target population, methods, study location and time periods. The prevalence of the hepatitis B surface antigen (HBsAg) in blood donors was reported to be $8.7 \%-9.6 \%$ in $2003-$ 2006. In the years 2011-2012, the reported HBsAg prevalence among women (including pregnant women) ranged from 0\%-9.5\% and among children aged 5-9 years from $1.7 \%-8.7 \%$,

44 depending on study location and age. The majority of strains characterized in Lao PDR belonged to genotypes $\mathrm{B}$ and $\mathrm{C}$.

Conclusion

47 Studies displayed considerable heterogeneity in populations, design and laboratory methods.

48 A high HBsAg prevalence was reported in adults including pregnant women. Low infant vaccination coverage and compromised vaccine immunogenicity were found. Only two studies 
medRxiv preprint doi: https://doi.org/10.1101/2022.01.23.21265872; this version posted January $25,2022$. The copyright holder for this preprint (which was not certified by peer review) is the author/funder, who has granted medRxiv a license to display the preprint in It is made available under a CC-BY-NC-ND 4.0 International license.

50 focused on HBV in risk populations, emphasizing the need for further studies to characterize 51 hepatitis B epidemiology in potentially vulnerable groups. Hepatitis B infection continues to

52 represent a substantial public health threat in the Lao PDR and needs to be monitored to inform

53 health authorities and to counteract over-burdening of the health care system. In order to end

54 mother to child transmission, vaccination coverage with the hepatitis B birth dose should be 55 increased. 
medRxiv preprint doi: https://doi.org/10.1101/2022.01.23.21265872; this version posted January $25,2022$. The copyright holder for this preprint (which was not certified by peer review) is the author/funder, who has granted medRxiv a license to display the preprint in It is made available under a CC-BY-NC-ND 4.0 International license .

\section{Introduction}

57 Hepatitis B and C, responsible for $96 \%$ of all hepatitis mortality, cause more deaths than either 58 HIV/AIDS, tuberculosis or malaria and yet seem to receive much less attention. The WHO

59 African and Western Pacific Regions are the most affected by the Hepatitis B virus (HBV).

60 Although most infections with HBV are asymptomatic, in some patients, acute infection can cause severe liver inflammation. Chronic infection with HBV can lead to liver cirrhosis and hepatocellular carcinoma $(1,2)$. The Coalition for Global hepatitis elimination estimated that globally $40 \%$ of liver cancer deaths could be attributed to HBV and the global number of HBVrelated deaths was estimated at more than half a million in 2019 (3).

HBV is grouped into at least 9 recognized genotypes (A to I), and one presumable genotype "J", each with a distinct geographic distribution. Evidence suggests that the HBV genotypes are related to HBV transmission modes and clinical outcomes (4-7). In Asia, genotypes B and C dominate largely $(8,9)$ and are associated with vertical transmission $(4)$.

Even though HBV is recognized as a major public health threat in the Lao PDR, it is challenging to provide quantitative epidemiological data about the HBV prevalence in the country. This is due to several reasons, including an inadequate surveillance system (10), the geographic and ethnic heterogeneity of the country and limited HBV testing. Understanding the HBV epidemiology in Lao PDR is important for improving vaccination, testing and treatment strategies.

Routine vaccination for children is free of charge in Lao PDR. Since 2001, HBV containing vaccines were gradually introduced in the routine national immunization schedule at 6,10 and 14 weeks of age. Currently, HBV vaccination is administered as part of the pentavalent routine infant vaccine in combination with diphtheria, tetanus, pertussis and Haemophilus influenzae type b (DTPw-HepB-Hib). Vaccination coverage rates vary regionally, but the nationwide 
medRxiv preprint doi: https://doi.org/10.1101/2022.01.23.21265872; this version posted January $25,2022$. The copyright holder for this preprint (which was not certified by peer review) is the author/funder, who has granted medRxiv a license to display the preprint in It is made available under a CC-BY-NC-ND 4.0 International license .

80

\section{Methods}

\section{Literature review and study selection}

99 A systematic review of peer-reviewed literature on HBV in the Lao PDR was conducted

coverage of 3 doses of the DTPw-HepB-Hib reached 84\% in 2018 (11). The monovalent HBV birth dose was introduced in Lao PDR in 2003 (12,13), but coverage rates were only 55\% in 2018 (11). The low coverage rates for the birth dose are particularly concerning since motherto-child transmission (MTCT) is one of the main routes of transmission in endemic countries (14). To date, only pregnant women are routinely screened for HBV during antenatal care visits, but immunoglobulin and anti-viral treatment are not readily available in the Lao PDR. The high prevalence of HBV infections in the adult Lao population contributes to the high levels of liver cancer $\left(22.4\right.$ per 100,$000 ; 5^{\text {th }}$ highest worldwide (15)) and will likely continue to perpetuate there.

Despite several studies in Lao PDR, our insights in the epidemiology of Hepatitis B in the country are still fragmented. This systematic review, the first in Lao PDR, will provide an upto-date summary of the HBV situation in the country. We aim to address the following questions: which data are available? Which conclusions can be drawn for national prevention and intervention strategies? What are the specific modalities of HBV transmission or susceptibility in particular risk groups? What are the prevalent HBV genotypes in the Lao PDR? What are current knowledge gaps?

following the PRISMA statement guidelines (16). PubMed and ScienceDirect (Elsevier) were searched by using the following key words: "Lao PDR" (or "Laos" or "Lao People's Democratic Republic") in combination with "hepatitis B" (or "HBV"), resulting in the full 
medRxiv preprint doi: https://doi.org/10.1101/2022.01.23.21265872; this version posted January 25,2022 . The copyright holder for this preprint (which was not certified by peer review) is the author/funder, who has granted medRxiv a license to display the preprint in It is made available under a CC-BY-NC-ND 4.0 International license .

103 search term “(("hepatitis B") OR ("HBV") OR ("jaundice")) AND (("Lao PDR") OR ("Lao

104 People's Democratic Republic") OR ("Laos"))”. The last day of search was 16.04.2021.

105 All articles were managed with the bibliographic management tool EndNote. Duplicate entries

106 were removed. All peer-reviewed studies reporting prevalence of HBV infection or HBV

107 genotype distribution in the Lao PDR and published between 01.01.1990 and 16.04.2021 were

108 included. Reports were screened and all reports which did not meet the eligibility criteria or

109 were reviews, book chapters, case reports, or conference abstracts were removed (Fig 1).

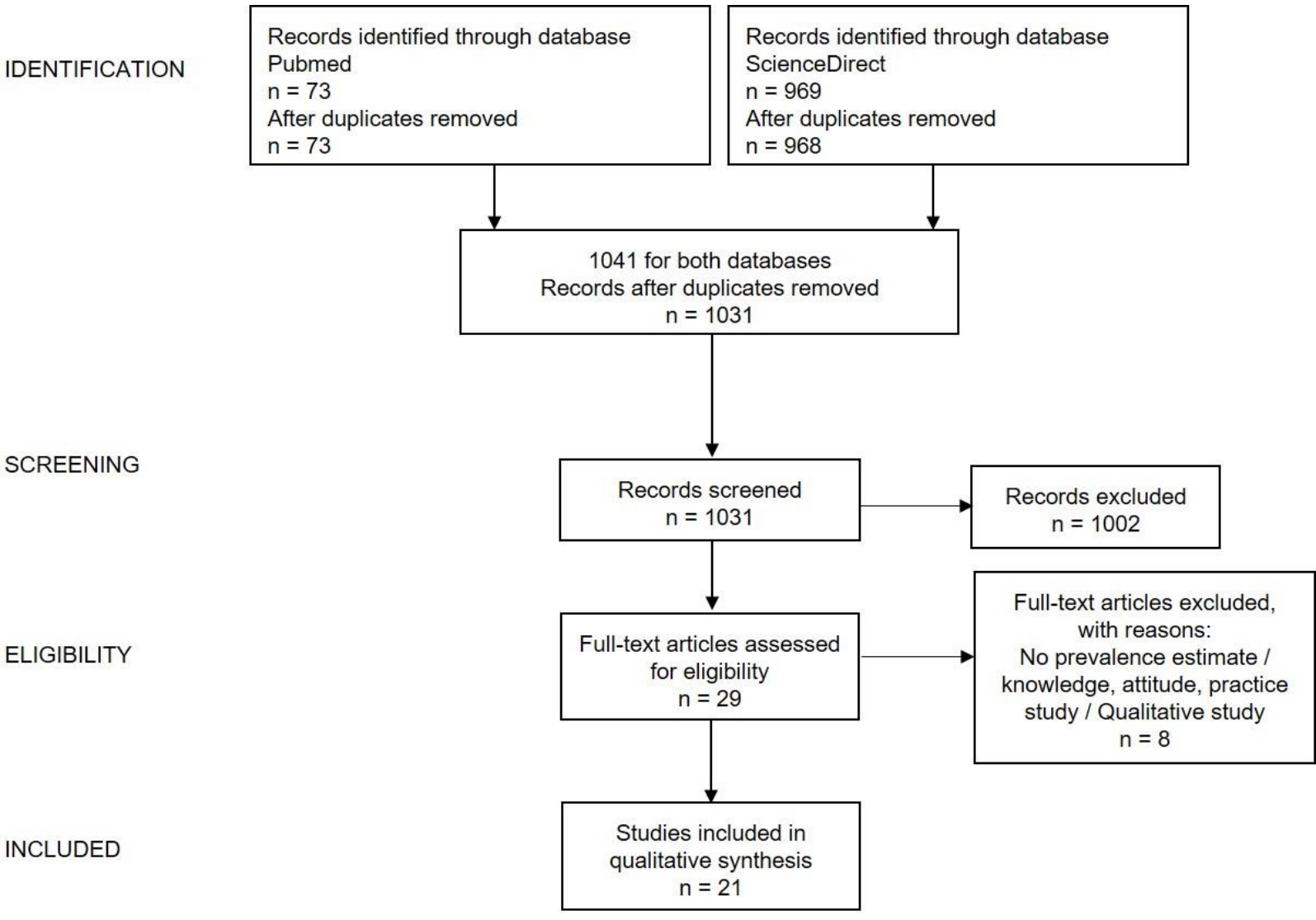

112 Fig 1 Flow diagram of the systematic review regarding Hepatitis B genotypes and Hepatitis B prevalence in the Lao 
medRxiv preprint doi: https://doi.org/10.1101/2022.01.23.21265872; this version posted January $25,2022$. The copyright holder for this preprint (which was not certified by peer review) is the author/funder, who has granted medRxiv a license to display the preprint in It is made available under a CC-BY-NC-ND 4.0 International license .

\section{Data analysis}

116 After selection of eligible studies, the following study data were extracted and entered into a

117 table: study identification data (first author, publication year and journal of publication), study

118 period, location, population, design, age of participants and estimates of prevalence of HBV

119 markers or HBV genotype distribution. Prevalence of the hepatitis B surface antigen (HBsAg)

120 was defined as the main primary outcome in addition to the prevalence of other HBV markers

121 indicating past infection (anti-Hepatitis B core antigen antibodies; anti-HBc) or past

122 infection/vaccination (anti-Hepatitis B surface antigen antibodies; anti-HBs). HBV genotype

123 distribution was included as secondary outcome. Due to the scarcity of HBV prevalence studies

124 in the Lao PDR and the heterogeneity of available studies, limitations and possible study biases

125 were discussed for each study individually. 
medRxiv preprint doi: https://doi.org/10.1101/2022.01.23.21265872; this version posted January $25,2022$. The copyright holder for this preprint (which was not certified by peer review) is the author/funder, who has granted medRxiv a license to display the preprint in It is made available under a CC-BY-NC-ND 4.0 International license .

\section{Results}

\section{General scope}

129 Of the 1031 identified references, 1002 were excluded after screening the title or/and abstract.

130 Of the remaining 29 articles, 21 were deemed eligible for inclusion in the systematic review

131 (Table 1).

132 From the three articles which investigated the genotype distribution of HBV in the Lao PDR

133 (17-19), two studies also reported HBsAg prevalence $(18,19)$. The remaining 18 articles

134 focused solely on the prevalence of HBV markers. Four studies were conducted in first-time

135 blood donors (17-20), two studies investigated the aetiology of jaundice and hepatitis in

136 Vientiane $(21,22), 12$ studies were conducted in the general population (including pregnant

137 women) (12,23,32,33,24-31) and three studies focused on risk groups (34-36).

138 In terms of study design, almost all studies were cross-sectional $(n=17)$, one study was a

139 retrospective analysis of medical records, one study was an aetiological study, one study was

140 a case-control study and one study was a prospective study. 
medRxiv preprint doi: https://doi.org/10.1101/2022.01.23.21265872; this version posted January $25,2022$. The copyright holder for this preprint (which was not certified by peer review) is the author/funder, who has granted medRxiv a license to display the preprint in It is made available under a CC-BY-NC-ND 4.0 International license .

\begin{tabular}{|c|c|c|}
\hline Year & Authors & Title \\
\hline 1998 & Bounlu et al. & Acute Jaundice in Vientiane, Lao People's Democratic Republic \\
\hline 2007 & Jutavijittum et al. & Seroprevalence of Hepatitis B and C virus infections among Lao blood donors \\
\hline 2008 & Olinger et al. & Possible new hepatiits B virus genotype, Southeast Asia \\
\hline 2010 & Syhavong et al. & The infective causes of hepatitis and jaundice amongst hospitalised patients in Vientiane, Laos \\
\hline 2012 & Andernach et al. & $\begin{array}{l}\text { A High Variability of Mixed Infections and Recent } \\
\text { Recombinations of Hepatitis B Virus in Laos }\end{array}$ \\
\hline 2013 & Jutavijittum et al. & Occult hepatitis B infections among blood donors in Lao PDR \\
\hline 2014 & Black et al. & $\begin{array}{l}\text { Hepatitis B virus in the Lao People's Democratic Republic: a cross sectional serosurvey in different } \\
\text { cohorts }\end{array}$ \\
\hline 2014 & Xeutavongsa et al. & $\begin{array}{l}\text { Chronic Hepatitis B Prevalence among Children and Mothers: Results from a Nationwide, } \\
\text { Population-Based Survey in Lao People's Democratic Republic }\end{array}$ \\
\hline 2015 & Black et al. & $\begin{array}{l}\text { Serosurveillance of Vaccine Preventable Diseases and Hepatitis C in Healthcare Workers from Lao } \\
\text { PDR }\end{array}$ \\
\hline 2015 & Komada et al. & $\begin{array}{l}\text { Seroprevalence of chronic hepatitis B, as determined from dried blood spots, among children and } \\
\text { their mothers in central Lao People's Democratic Republic: a multistage, stratified cluster sampling } \\
\text { survey }\end{array}$ \\
\hline 2016 & Jutavijittum et al. & High rate of Hepatitis B virus mother-to-child transmission in Lao People's Democratic Republic \\
\hline 2016 & Xaydalasouk et al. & Assessment of mother-to-child HBV transmission at the prenatal consultation in Vientiane, Laos \\
\hline 2016 & Evdokimov et al. & $\begin{array}{l}\text { Low and disparate seroprotection after pentavalent childhood } \\
\text { vaccination in the Lao People's Democratic Republic: a cross-sectional } \\
\text { study }\end{array}$ \\
\hline 2017 & Choisy et al. & $\begin{array}{l}\text { Prevalence of Hepatitis B Virus Infection among Pregnant Women Attending Antenatal Clinics in } \\
\text { Vientiane, Laos, 2008-2014 }\end{array}$ \\
\hline 2018 & Xaydalasouk et al. & $\begin{array}{l}\text { Seroprevalence and risk factors of hepatitis B and C virus infections in female workers of Lao } \\
\text { garment factories }\end{array}$ \\
\hline 2019 & Hefele et al. & $\begin{array}{l}\text { Seroprotection at different levels of the health care system after routine vaccination } \\
\text { with DTPw-HepB-Hib in Lao PDR }\end{array}$ \\
\hline 2019 & Norizuki et al. & $\begin{array}{l}\text { Serologic testing of randomly selected children after hepatitis B vaccination: a cross-sectional } \\
\text { population-based study in Lao People's Democratic Republic. }\end{array}$ \\
\hline 2019 & Latthaphasvan et al. & $\begin{array}{l}\text { Perinatal hepatitis B virus transmission in Lao } \\
\text { PDR: A prospective cohort study }\end{array}$ \\
\hline 2020 & Hefele et al. & $\begin{array}{l}\text { Lasting benefit of infant hepatitis B vaccination in adolescents in the Lao People's Democratic } \\
\text { Republic }\end{array}$ \\
\hline 2020 & Mangkara et al. & Hepatitis B virus in Lao dentists: A cross-sectional serological study \\
\hline 2021 & Xaydalasouk et al. & $\begin{array}{l}\text { Age-stratified seroprevalence of vaccine-preventable infectious disease in Saravan, Southern Lao } \\
\text { People's Democratic Republic. }\end{array}$ \\
\hline
\end{tabular}

\section{Patients with acute jaundice}

144 An early report investigated the aetiology of acute jaundice in three hospitals in Vientiane in

145 1995-1996 (22) (Table 2). In this study, HBV was identified as one of the major causes of acute

146 viral hepatitis (10\% IgM anti-HBc), the most common being Hepatitis A (14\%). HBV was also

147 identified as an important cause of hepatitis or jaundice in hospitalized patients in Vientiane

148 from 2001 to 2004 (21).

149 HBV seroprevalence 
medRxiv preprint doi: https://doi.org/10.1101/2022.01.23.21265872; this version posted January $25,2022$. The copyright holder for this preprint (which was not certified by peer review) is the author/funder, who has granted medRxiv a license to display the preprint in It is made available under a CC-BY-NC-ND 4.0 International license .

150 The 18 seroprevalence studies varied in sample size, target population, methods, location and

151 time periods (Table 2). All studies but one provided HBsAg estimates and 9 studies also 152 investigated the prevalence of anti-HBs and anti-HBc antibodies.

153 
Table 2 Data regarding HBV prevalence in the Lao PDR

\begin{tabular}{|c|c|c|c|c|c|c|c|c|c|c|c|c|c|}
\hline Study year & Ref & Method & Cohort & $\mathbf{N}$ & Study site & Age & N subset & $\begin{array}{c}\text { HBsAg + } \\
(\%)\end{array}$ & $\begin{array}{c}\text { IgM anti- } \\
\text { HBc }+(\%)\end{array}$ & $\begin{array}{c}\text { anti-HBs + I } \\
\text { anti-HBc- } \\
(\%) \\
\end{array}$ & $\begin{array}{c}\text { anti-HBs - / } \\
\text { anti-HBc -(\%) }\end{array}$ & $\begin{array}{c}\text { anti-HBs + / } \\
\text { anti-HBc + (\%) }\end{array}$ & $\begin{array}{c}\text { anti-HBs - / anti- } \\
\text { HBc }+(\%)\end{array}$ \\
\hline 1995-1996 & $(22)$ & ELISA & $\begin{array}{l}\text { Patients with } \\
\text { jaundice }\end{array}$ & 208 & VTN & & & & 10.0 & & & & \\
\hline 2001-2004 & (21) & ELISA & $\begin{array}{l}\text { Patients with } \\
\text { jaundice }\end{array}$ & 392 & VTN & & & 18.0 & 16.0 & & & & \\
\hline \multirow[t]{3}{*}{ 2003-2005 } & $(20)$ & $\begin{array}{l}\text { particle } \\
\text { agglutination } \\
\text { test, ELISA }\end{array}$ & $\begin{array}{l}\text { First-time blood } \\
\text { donors }\end{array}$ & 13897 & VTN, BLX & $17-66$ y & & 8.70 & & & & & \\
\hline & & & Male & & & & 10099 & 9.7 & & & & & \\
\hline & & & Female & & & & 3798 & 6.2 & & & & & \\
\hline 2004-2006 & $(18)$ & NA & $\begin{array}{l}\text { First-time blood } \\
\text { donors }\end{array}$ & 9157 & $\begin{array}{l}\text { VTN, central } \\
\text { provinces }\end{array}$ & NA & & 8.80 & & & & & \\
\hline 2006 & (19) & ELISA & $\begin{array}{l}\text { First-time blood } \\
\text { donors }\end{array}$ & 906 & VTN, BLX & $16-53$ y & & 9.60 & & 1.7 & 54.6 & 26.0 & 17.7 \\
\hline $2008-2014$ & (27) & ELISA & Pregnant women & 13238 & VTN & $13-48$ y & & 5.44 & & & & & \\
\hline 2008-2009 & $(25)$ & RT/ELISA & Pregnant women & 3000 & VTN & $15-49$ y & & 5.80 & & & & & \\
\hline \multirow[t]{16}{*}{2011} & (12) & ELISA & Infants & 192 & All & $9-16 \mathrm{~m}$ & & 0.50 & & 59.90 & 28.10 & 5.70 & 6.30 \\
\hline & & & & & VTN & $9-16 \mathrm{~m}$ & 94 & 1.10 & & 64.90 & 24.50 & 3.20 & 7.50 \\
\hline & & & & & LPB & $9-16 \mathrm{~m}$ & 98 & 0.00 & & 55.10 & 31.60 & 8.20 & 5.10 \\
\hline & & & Pregnant women & 388 & All & $16-46$ y & & 8.20 & & 7.50 & 43.00 & 29.90 & 19.60 \\
\hline & & & & & VTN & $16-46$ y & 189 & 9.50 & & 3.20 & 51.90 & 29.10 & 15.90 \\
\hline & & & & & LPB & $16-46$ y & 199 & 7.00 & & 11.60 & 34.70 & 30.70 & 23.10 \\
\hline & & & School children ${ }^{\mathrm{a}}$ & 1689 & All & $5-19$ y & & 7.90 & & 17.60 & 61.90 & 9.10 & 11.40 \\
\hline & & & & & & $5-9$ y & 393 & 4.83 & & 31.30 & 56.74 & 5.85 & 6.11 \\
\hline & & & & & & $10-19 \mathrm{y}$ & 1296 & 10.19 & & 13.43 & 63.43 & 10.03 & 13.12 \\
\hline & & & & & LPB & $5-19$ y & 596 & 8.40 & & 22.00 & 53.40 & 14.40 & 10.20 \\
\hline & & & & & & $5-9$ y & 185 & 4.86 & & 37.30 & 50.81 & 7.57 & 4.32 \\
\hline & & & & & & $10-19 y$ & 411 & 14.11 & & 15.09 & 54.50 & 17.52 & 12.90 \\
\hline & & & & & BLX & $5-19$ y & 560 & 3.60 & & 19.30 & 63.90 & 6.60 & 10.20 \\
\hline & & & & & & $5-9$ y & 185 & 4.32 & & 28.11 & 61.62 & 4.32 & 5.95 \\
\hline & & & & & & $10-19$ y & 375 & 3.47 & & 14.93 & 65.07 & 7.73 & 12.27 \\
\hline & & & & & SVK & $5-19$ y & 533 & 11.80 & & 10.90 & 69.20 & 5.80 & 14.10 \\
\hline
\end{tabular}




\begin{tabular}{|c|c|c|c|c|c|c|c|c|c|c|c|c|}
\hline & & & & & & $5-9 y$ & 23 & 8.70 & 8.70 & 65.22 & 4.35 & 21.74 \\
\hline & & & & & & $10-19 y$ & 510 & 11.96 & 10.98 & 69.41 & 5.69 & 13.92 \\
\hline \multirow[t]{12}{*}{2011} & (24) & $\begin{array}{l}\text { filter paper, } \\
\text { CLIA }\end{array}$ & Children & 911 & All & $5-9 y$ & & 2.09 & & & & \\
\hline & & & & & VTN Capital & $5-9 y$ & 186 & 2.15 & & & & \\
\hline & & & & & VTN Province & $5-9 y$ & 182 & 2.75 & & & & \\
\hline & & & & & BLX & $5-9 y$ & 179 & 3.91 & & & & \\
\hline & & & & & KMN & $5-9 y$ & 180 & 1.11 & & & & \\
\hline & & & & & SVK & $5-9$ y & 184 & 1.63 & & & & \\
\hline & & & Mothers & 911 & All & $15-45$ y & & 4.10 & & & & \\
\hline & & & & & VTN Capital & $15-45$ y & 186 & 3.76 & & & & \\
\hline & & & & & VTN Province & $15-45$ y & 182 & 6.59 & & & & \\
\hline & & & & & BLX & $15-45$ y & 179 & 5.59 & & & & \\
\hline & & & & & KMN & $15-45$ y & 180 & 2.78 & & & & \\
\hline & & & & & SVK & $15-45$ y & 184 & 3.26 & & & & \\
\hline \multirow[t]{2}{*}{2011} & (31) & $\begin{array}{l}\text { Filter paper, } \\
\text { CLIA }\end{array}$ & Children & 911 & $\begin{array}{l}\text { VTN, VTN } \\
\text { province, BLX, } \\
\text { KMN, SVK } \\
\text { VTN, VTN }\end{array}$ & $5-9 y$ & & 2.30 & $0.7^{\mathrm{b}}$ & & & \\
\hline & & & Mothers & 911 & $\begin{array}{l}\text { Province, } \\
\text { BLX, KMN, } \\
\text { SVK }\end{array}$ & $15-45$ y & & 4.40 & & & & \\
\hline \multirow[t]{8}{*}{2012} & (23) & Rapid test & Children & 965 & NA & $5-9 y$ & & 1.70 & & & & \\
\hline & & & Mothers & 965 & NA & $15-45$ y & & 2.90 & & & & \\
\hline & & & & & & $15-19 y$ & 4 & 0.00 & & & & \\
\hline & & & & & & $20-24$ y & 85 & 3.53 & & & & \\
\hline & & & & & & $25-29 y$ & 294 & 2.72 & & & & \\
\hline & & & & & & $30-34$ y & 275 & 3.27 & & & & \\
\hline & & & & & & $35-39$ y & 176 & 1.70 & & & & \\
\hline & & & & & & $40-45$ y & 131 & 3.05 & & & & \\
\hline 2013 & (26) & ELISA & Pregnant women & 200 & VTN & $14-39$ y & & 8.00 & & & & \\
\hline 2013 & (12) & ELISA & Pre-school children & 132 & HPN & $1-4 y$ & & 4.50 & 13.60 & 65.10 & 11.40 & 9.90 \\
\hline
\end{tabular}




\begin{tabular}{|c|c|c|c|c|c|c|c|c|c|c|c|c|}
\hline 2013 & (35) & ELISA & $\begin{array}{l}\text { Health care } \\
\text { workers }\end{array}$ & 1128 & $\begin{array}{l}\text { VTN, BLX, } \\
\text { HPN }\end{array}$ & $15-69$ y & & 8.00 & 21.00 & 30.20 & 32.20 & 16.70 \\
\hline \multirow[t]{2}{*}{ 2013-2014 } & (28) & ELISA & $\begin{array}{l}\text { Vaccinated } \\
\text { children }\end{array}$ & 1039 & $\begin{array}{l}\text { VTN, BLX, } \\
\text { KMN }\end{array}$ & $9-50 \mathrm{~m}$ & & 0.96 & 34.1 & 58.13 & 3.85 & 3.95 \\
\hline & & & Mothers & 1105 & $\begin{array}{l}\text { VTN, BLX, } \\
\text { KMN }\end{array}$ & $15-50 \mathrm{y}$ & & 7.00 & 3.71 & 56.02 & 21.45 & 18.82 \\
\hline 2015 & (34) & ELISA & Garment workers & 400 & VTN & $15-57$ y & & 4.01 & 3.26 & 50.13 & 25.81 & 20.8 \\
\hline \multirow[t]{2}{*}{2015} & (30) & $\begin{array}{l}\text { RT, ELISA, } \\
\text { PCR }\end{array}$ & $\begin{array}{l}\text { HBV-infected } \\
\text { mothers }\end{array}$ & 153 & VTN & $24-30$ y & & 100 & & & & \\
\hline & & & infants & 120 & VTN & & & 4.2 & & & & \\
\hline 2017 & (29) & ELISA & $\begin{array}{l}\text { Vaccinated } \\
\text { children }\end{array}$ & 805 & BLX & $8-28 \mathrm{~m}$ & & 0.75 & 69.94 & 26.96 & 1.86 & 1.24 \\
\hline \multirow[t]{7}{*}{2017} & (33) & ELISA & General population & 2463 & SAR & $5-90$ y & & 3.8 & 9.9 & 56.9 & 15.8 & 17.4 \\
\hline & & & & & & $5-10 y$ & 258 & 0.00 & 39.53 & 58.91 & 0.78 & 0.78 \\
\hline & & & & & & $11-20 y$ & 639 & 2.80 & 11.42 & 73.08 & 8.45 & 7.04 \\
\hline & & & & & & $21-30 y$ & 475 & 4.60 & 4.63 & 65.26 & 16.21 & 13.89 \\
\hline & & & & & & $31-40 \mathrm{y}$ & 336 & 5.40 & 4.46 & 54.17 & 19.35 & 22.02 \\
\hline & & & & & & $41-50 y$ & 313 & 4.50 & 3.83 & 46.33 & 18.85 & 30.99 \\
\hline & & & & & & $>50 \mathrm{y}$ & 442 & 5.00 & 4.52 & 33.03 & 29.64 & 32.81 \\
\hline \multirow[t]{3}{*}{2018} & $(32)$ & ELISA & Adolescents & 779 & All & $11-18 \mathrm{y}$ & & 2.96 & 17.35 & 73.14 & 5.14 & 4.37 \\
\hline & & & & & VTN & $11-18$ y & 388 & 1.55 & 19.33 & 74.23 & 3.87 & 2.58 \\
\hline & & & & & BLX & $11-18 \mathrm{y}$ & 391 & 4.10 & 15.38 & 72.05 & 6.41 & 6.15 \\
\hline \multirow[t]{3}{*}{2018} & (36) & ELISA & Dentists & 317 & VTN & $15-63$ y & & 5.0 & 13.6 & 48.6 & 19.6 & 18.3 \\
\hline & & & Male & & & & 104 & 7.0 & 13.5 & 37.5 & 20.2 & 28.8 \\
\hline & & & Female & & & & 213 & 3.8 & 13.6 & 54 & 19.2 & 13.1 \\
\hline
\end{tabular}

VTN = Vientiane, BLX = Bolikhamxay, KMN = Khammouane, HPN = Huaphan, LPB = Luang Prabang, SVK = Savannakhet, SAR = Saravan; $m=$ months, $y=$ years, NA = not available, CLIA = chemiluminescence immunoassay

${ }^{a}$ Data in study (12) is reported only for the overall age group. The data was requested from the author and split into the age groups 5 to 9 and 10 to 19 for the purpose of this review

banti-HBs IgG overall (no information about anti-HBc status given) 
medRxiv preprint doi: https://doi.org/10.1101/2022.01.23.21265872; this version posted January 25, 2022. The copyright holder for this preprint (which was not certified by peer review) is the author/funder, who has granted medRxiv a license to display the preprint in

It is made available under a CC-BY-NC-ND 4.0 International license .

156

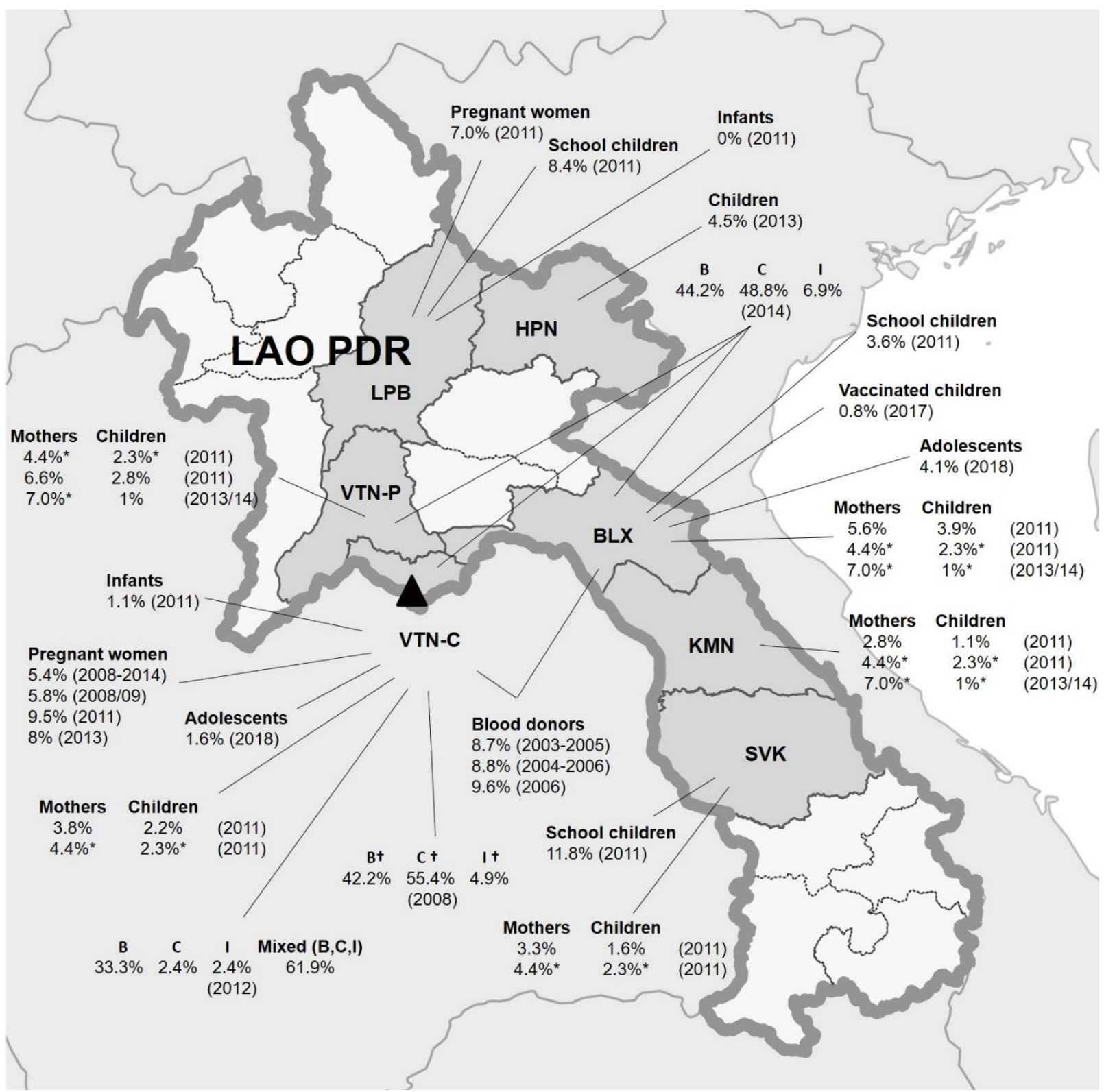

Fig 2 Geographical distribution of HBsAg prevalence in the general population and HBV genotypes in the Lao PDR. HBsAg prevalences in sub-populations are depicted per province (if information was given in the article), with the study year in brackets. $*=$ HBsAg estimate was given as an overall estimate of several study locations. $\uparrow=$ study location in article stated as Vientiane Capital and Central provinces. The location of Vientiane Capital is indicated by the black triangle. LPB $=$ Luang

163 Prabang, HPN = Huaphan, VTN-P = Vientiane Province, VTN-C = Vientiane Capital, BLX = Bolikhamxay, KMN =

164 Khammouane, $\mathrm{SVK}=$ Savannakhet, $\mathrm{SAR}=$ Saravan. 
medRxiv preprint doi: https://doi.org/10.1101/2022.01.23.21265872; this version posted January $25,2022$. The copyright holder for this preprint (which was not certified by peer review) is the author/funder, who has granted medRxiv a license to display the preprint in It is made available under a CC-BY-NC-ND 4.0 International license .

\section{General population}

167 Most seroprevalence studies assessed the HBV seroprevalence in women and children;

168 however, one cross-sectional study in Saravan province also reported HBV prevalence in men.

169 Reported HBsAg prevalence estimates for women ranged from 0 to $9.5 \%$ in the general

170 population (Table 2).

171 The earliest estimate of $6.2 \%$ chronic HBV infections in women was from the above study

172 focusing on blood donors between 2003 and 2005 (20). Similarly, a hospital-based study in

173 Vientiane from 2008 to 2009 found 5.8\% of pregnant women aged 15-49 years to be HBsAg

174 positive (25) (Table 2, Fig 2).

175 Between 2011 and 2012, four other studies characterized the HBV prevalence in women and

176 children $(12,23,24,31)$.

177 In 2011, a stratified, multistage, cluster sampling survey was conducted in central Lao PDR

178 including 911 mother-child pairs (24). The overall HBsAg seroprevalence was $4.1 \%$ in the

179 mothers (15-45 years) (Table 2, Figure 2). Estimated HBsAg prevalence rates differed between

180 study sites in Vientiane municipality (3.8\%), Vientiane province (6.6\%), Bolikhamxay (5.6\%),

181 Khammuane (2.8\%) and Savannakhet (3.3\%).

182 In a similar study in mothers (15-45 years) and their children in the same central provinces in

183 the same year (2011), (31) found an HBsAg prevalence of $4.4 \%$ in the mothers.

184 A non-randomized, cross-sectional seroprevalence study including multiple cohorts (12)

185 reported $9.5 \%$ and $7 \%$ HBsAg rates in pregnant women (16-46 years) in Vientiane and Luang

186 Prabang, respectively, and nearly half of all pregnant women were positive for anti-HBc $187(49.5 \%)$. 
medRxiv preprint doi: https://doi.org/10.1101/2022.01.23.21265872; this version posted January $25,2022$. The copyright holder for this preprint (which was not certified by peer review) is the author/funder, who has granted medRxiv a license to display the preprint in It is made available under a CC-BY-NC-ND 4.0 International license.

In 2012, in another multistage, cluster sampling mother-child survey, HBsAg prevalence was only $2.9 \%$ in mothers (15-45 years) (23), but there was no indication of the specific study sites within Lao PDR.

191 Tree of the mother-child studies $(23,24,31)$ used cluster sampling to estimate HBsAg 192 prevalence rates in the Lao PDR, but they differed in their testing methodology. In two studies 193 (24,31), samples were collected onto filter paper via finger prick and analysed by 194 chemiluminescence immunoassay while in another study (23), a rapid test was used to 195 determine HBsAg status. The authors of one study (24) remarked in their Discussion on issues 196 regarding the utilization of dried blood spots in HBV serosurveys since there are not many 197 reports investigating the diagnostic reliability in the context of field work.

198 A non-randomized cross-sectional seroprevalence study conducted in 2013/14 in 199 Khammouane, Vientiane and Boulhikhamxay provinces (28) also recruited mother-child pairs, 200 but focused on children with a complete course of the DTPw-HepB-Hib vaccine. Overall 201 HBsAg prevalence in mothers was 7\%, higher than the overall HBsAg prevalence reported in mothers by some of the above studies $(23,24,31)$, indicating regional variation or possibly different sensitivity and specificity of the techniques used for assessing HBsAg positivity.

204 A study conducted in 2013 in Vientiane capital reported the HBsAg seroprevalence to be 8\% 205 in pregnant women (14-39 years) (26). Another retrospective study during 2008-2014 described HBsAg prevalence among pregnant women visiting the Mahosot hospital in

207 Vientiane as $5.4 \%$ (27). A slight yet steady decline of the prevalence was reported over the 208 period of the study. These rates in pregnant women were somewhat higher than the prevalence 209 of HBsAg reported in women in two of the mother-child studies $(23,24)$.

210 The cross-sectional study conducted in Saravan reported 33.2\% of the total tested population 211 to have anti-HBc antibodies indicating previous exposure to HBV. The proportion of exposed 
medRxiv preprint doi: https://doi.org/10.1101/2022.01.23.21265872; this version posted January $25,2022$. The copyright holder for this preprint (which was not certified by peer review) is the author/funder, who has granted medRxiv a license to display the preprint in It is made available under a CC-BY-NC-ND 4.0 International license .

212 individuals increased with age and the proportion of exposure in males was significantly higher

213 than in females $(37.4 \%$ and $30.0 \% ; \mathrm{p}<0.0001)$. Overall, $5 \%$ of the general population were

214 chronically infected(33).

\section{Children and adolescents}

216 MTCT is one of the main routes of transmission in endemic countries (14). The hospital-based

217 study in Vientiane in 2008/09 (25) which found 5.8\% pregnant women aged 15-49 years to be

218 HBsAg positive reported that as many as $21 \%$ of infants born to these HBsAg positive mothers

219 were also HBsAg positive (Table 2). Unfortunately, the vaccination history of the children was

220 not recorded in this study and it is unknown if they had received the HBV birth dose, which

221 was introduced in 2003.

222 MTCT was investigated in a prospective-cohort study on HBsAg positive pregnant women and their new-borns from 2015-2017 in Vientiane Capital (30). HBV vaccination was provided for all new-borns according to the immunization schedule. The authors reported a relatively low rate of MTCT considering that Hepatitis B immunoglobulin and anti-viral treatment are not readily available in the Lao PDR: $4 \%$ of children born to chronically infected mothers were positive for HBsAg. 15 of the 120 infants showed unsatisfactory protective antibody levels after vaccination when tested at 6 months of age (anti-HBs <10 IU/L), indicating the need for improving vaccine management.

230 The three multistage cluster sampling studies $(23,24,31)$ found an overall $\mathrm{HBsAg}$ seroprevalence between $1.7 \%$ and $2.3 \%$ among 5 to 9 year old children (Table 1). Again, the HBsAg prevalence reported by another study (12) was more than twice as high (4.8\%) in children of the same age range.

234 In a study from 2011, (31), participants were tested for both HBsAg and anti-HBs. The study reported that only $0.7 \%$ of all the included children had a positive anti-HBs titer (with or 
medRxiv preprint doi: https://doi.org/10.1101/2022.01.23.21265872; this version posted January $25,2022$. The copyright holder for this preprint (which was not certified by peer review) is the author/funder, who has granted medRxiv a license to display the preprint in It is made available under a CC-BY-NC-ND 4.0 International license.

without documented vaccination) approximately 3 to 9 years after being presumably vaccinated. None of the children with a documented vaccination history showed protective anti-HBs titers (here defined as $10 \mathrm{UI} / \mathrm{L}$ ).

A separate study (12) reported substantial heterogeneity in terms of vaccination coverage and health care access in the Lao PDR in 2011. Four sub-populations from different age groups were investigated regarding the prevalence of HBV markers. While infants showed a low prevalence of $\mathrm{HBsAg}(0.5 \%)$ and a relatively high rate of the serological vaccination profile (59.9\%), school children born before and after the introduction of the vaccine in 2001 had a much higher HBsAg prevalence (7.9\%). In 2011, school children (age 5 to 9 years) were included in this study (12) and one mother-child study (24) from the same location. While the prevalence of HBsAg in these school children reported from Bolikhamxay was similar in both studies (3.6\% and 3.9\%), the mother-child study (24) reported only $1.63 \%$ of the children to be HBsAg positive in Savannakhet, in contrast to the school children study (12), which found $8.7 \%$ of the children to be infected. Reasons for the discrepancy in HBsAg prevalences are not clear, but the studies differed greatly in design and methodology. In the mother-child study (24), participants were selected randomly, samples were collected onto filter paper via finger prick and analysed by chemiluminescence immunoassay while in the school children study (12), recruitment took place in the framework of a national measles and rubella vaccination campaign, samples were taken by venipuncture and analysed by enzyme-linked immunosorbent assay.

Although HBV vaccination was introduced in the national immunization schedule in 2001, only $13.6 \%$ of pre-school children (1-4 years) from a rural area in Huaphan province in Northern Lao PDR showed the serological vaccination profile in 2013 and $4.5 \%$ were positive for HBsAg. This indicated that vaccine coverage was very low in this setting even 10 years after the introduction of the vaccine (12) (Table 2, Fig 2). 
medRxiv preprint doi: https://doi.org/10.1101/2022.01.23.21265872; this version posted January $25,2022$. The copyright holder for this preprint (which was not certified by peer review) is the author/funder, who has granted medRxiv a license to display the preprint in It is made available under a CC-BY-NC-ND 4.0 International license .

261 In a study in 2013/14 less than 1\% of children aged 9-50 months with documented three doses

262 of DTPw-HepB-Hib were chronically infected, despite a low proportion of children showing

263 a serological vaccination profile (34\%) (28). These results show that in addition to low vaccine

264 coverage, vaccine immunogenicity is a problem in the Lao PDR. A follow-up study in 2017

265 reported a considerable improvement in vaccine immunogenicity and a decrease in HBV

266 infection rates: HBsAg prevalence declined from $1.8 \%$ to $0.8 \%$, when only children in the same

267 age range were compared between 2013/14 and 2017 (29). Results indicated significantly lower

268 protection rates in remote areas.

269 In 2018, a cross-sectional seroprevalence study investigated the impact of the HBV vaccination

270 in central Lao PDR in randomized adolescent school children from 11 to 18 years, born just

271 before or after the infant vaccine introduction (32). In this study, the proportion of students

272 with a serological vaccination profile increased after the introduction of HBV vaccine and a

273 sizable number were still protected 11 years after vaccination. In addition, the prevalence of

274 past infection decreased.

\section{Risk groups}

276 A study conducted in 2013 revealed a very high proportion of health care workers to be 277 susceptible to HBV (35). Most participants included in the study were female (79.8\%). 8\%

278 were HBsAg carriers (11.5\% in males and 7.1\% in females) and about half (48.8\%) had anti-

$279 \mathrm{HBc}$ antibodies indicating previous exposure (Table 2). The HBsAg prevalence of $7.1 \%$ in

280 female health care workers was higher than reported for women in some studies $(23,24,31)$,

281 but is comparable to others (12,26,28). Dental workers in a study from 2018 also showed a

282 high proportion of previous exposure (37.8\% anti-HBc+) and $5 \%$ were chronically 283 infected(36). 
medRxiv preprint doi: https://doi.org/10.1101/2022.01.23.21265872; this version posted January $25,2022$. The copyright holder for this preprint (which was not certified by peer review) is the author/funder, who has granted medRxiv a license to display the preprint in It is made available under a CC-BY-NC-ND 4.0 International license .

284 A study in 2014 focused on female garment factory workers aged 15 to 57 years as a vulnerable 285 population (34). Although the HBsAg prevalence of $4 \%$ was lower than expected (Table 2),

286 the data suggested a significant association with sexual risk behaviour and very low levels of 287 knowledge and awareness regarding HBV. More than $40 \%$ of the women showed evidence of 288 past infection with HBV.

\section{Risk factors or predictors associated with HBV infection}

290 Although some studies found no risk factors associated with HBV infection status (37), others

291 have identified significant associations. HBsAg prevalence among blood donors was higher in

292 males and increased significantly with age $(19,20)$. In Saravan province, previous exposure to

293 HBV was significantly higher in males than females and increased with age (33). Chronic

294 infection in the mothers was a risk factor for chronic infection in children aged 5-9 years in

295 two studies $(23,24)$. Being born outside a health care facility was significantly associated with

296 chronic HBV infection in one of the studies (24), but not in the other. One study reported

297 decreasing HBsAg positivity rates in pregnant women according to study year, but not age

298 (27). Regarding the health care workers, HBsAg prevalence was higher in older participants and considerably lower in central hospitals, indicating that there may be differences in awareness and/or safety policies at different levels of the health care system (35).

\section{Genotype distribution}

302 We identified only 3 studies with HBV genotyping data in the Lao PDR (Table 3, Fig 2). The earliest study, published in 2008, reported a new genotype I (17). In another study, phylogenetic analyses of $42 \mathrm{HBV}$ strains from HBsAg positive first time blood donors revealed mixed infections of sub-genotypes B1, B2, B4, C1, C5, I1 and I2 (18). The third study from genotypes were reported for the Lao PDR. In all three studies, genotypes B and C, or a mix of both, were found most often. 
medRxiv preprint doi: https://doi.org/10.1101/2022.01.23.21265872; this version posted January $25,2022$. The copyright holder for this preprint (which was not certified by peer review) is the author/funder, who has granted medRxiv a license to display the preprint in It is made available under a CC-BY-NC-ND 4.0 International license.

Table 3 Summary of the studies conducted on prevalence of HBV genotypes in the Lao PDR

\begin{tabular}{|c|c|c|c|c|c|c|c|c|}
\hline \multirow[t]{2}{*}{ Ref } & \multirow[t]{2}{*}{$\begin{array}{l}\text { Study } \\
\text { location }\end{array}$} & \multirow{2}{*}{$\begin{array}{l}\text { Year of } \\
\text { sample } \\
\text { collection }\end{array}$} & \multirow[t]{2}{*}{$\begin{array}{l}\text { study } \\
\text { population }\end{array}$} & \multirow[t]{2}{*}{$\mathbf{n}$} & \multicolumn{4}{|c|}{ Genotypes } \\
\hline & & & & & B & $\mathrm{C}$ & I & Mixed $(B, C, I)$ \\
\hline (17) & $\begin{array}{l}\text { VTN Capital, } \\
\text { central } \\
\text { provinces }\end{array}$ & NA & $\begin{array}{l}\text { blood } \\
\text { donors }\end{array}$ & 386 & $\begin{array}{l}163 \\
(42.2 \%)\end{array}$ & $\begin{array}{l}204 \\
(55.4 \%)\end{array}$ & $\begin{array}{l}19 \\
(4.9 \%)\end{array}$ & \\
\hline (18) & VTN Capital & 2004-2005 & $\begin{array}{l}\text { blood } \\
\text { donors }\end{array}$ & 42 & $\begin{array}{l}14 \\
(33.3 \%)\end{array}$ & $\begin{array}{l}1 \\
(2.4 \%)\end{array}$ & $\begin{array}{l}1 \\
(2.4 \%)\end{array}$ & $26(61.9 \%)$ \\
\hline (19) & $\begin{array}{l}\text { VTN Capital, } \\
\text { VTN } \\
\text { Province, } \\
\text { BLX }\end{array}$ & 2006 & $\begin{array}{l}\text { blood } \\
\text { donors }\end{array}$ & 43 & $\begin{array}{l}19 \\
(44.2 \%)\end{array}$ & $\begin{array}{l}21 \\
(48.8 \%)\end{array}$ & $\begin{array}{l}3 \\
(6.97 \%)\end{array}$ & \\
\hline
\end{tabular}

VTN = Vientiane; BLX = Bolikhamxay Province; NA = not available; $\mathrm{n}=$ samples screened

310

\section{Discussion}

313 This literature review provides an overview of studies investigating the genotype distribution

314 and HBV serology in different subgroups and regions and highlights that our understanding of

315 the epidemiology of Hepatitis B in the Lao PDR is incomplete. The aim of most of the studies

316 was to estimate the rates of chronic infection in the Lao population; however, there are also

317 some studies investigating the exposure to $\mathrm{HBV}$, the level of protection conferred through

318 vaccination against HBV or the genotype distribution.

319 Prevalence studies varied in study design and laboratory methods and included different

320 population groups and therefore generalised statements about hepatitis epidemiology in the Lao

321 PDR should be interpreted with caution. However, several important conclusions can be made,

322 namely; high rates of chronic infection in adults, including women of child-bearing age; low

323 infant vaccination coverage and compromised vaccine immunogenicity in particular regions;

324 recent evidence of reduction in infection in adolescents born after vaccine introduction.

325 The earliest estimates of chronic HBV infection in the Lao PDR ranging from 8.7 to $9.6 \%$ were

326 based on studies in blood donor samples derived from Vientiane Capital and central provinces 
medRxiv preprint doi: https://doi.org/10.1101/2022.01.23.21265872; this version posted January $25,2022$. The copyright holder for this preprint (which was not certified by peer review) is the author/funder, who has granted medRxiv a license to display the preprint in It is made available under a CC-BY-NC-ND 4.0 International license.

327 in the years 2003 to 2006 (18-20). The classification of countries into high ( $\geq 8 \% \mathrm{HBsAg}$ 328 prevalence), intermediate $(2-7 \%)$ and low $(<2 \%) \mathrm{HBV}$ endemicity is internationally recognized

329 (38). Based on this, Lao PDR would be considered as "highly endemic". However, while blood 330 donors may represent an approximation for the general population, these studies were only 331 conducted in central Lao PDR and do not provide any further information about other 332 characteristics of the participants, such as for example ethnicity. In addition, the data may not 333 mirror the current situation anymore as they are more than 14 years old.

334 Subsequent serological surveys provided further HBsAg estimates for women (ranging from 0 to $9.5 \%$ ) and children and adolescents aged 8 months to 19 years (ranging from $0 \%$ to $11.8 \%$ )

$336(12,20,23,25-29,31,32)$. One study estimated the rate of past infection for women at $40.3 \%$

337 (28). Drawbacks of these studies include non-randomized study design and the utilization of different testing methodology, which makes it difficult to compare the results. In addition, studies solely including women may underestimate the burden of hepatitis B. HBV screening 340 of pregnant women and raising awareness in the general population are still very important 341 public health interventions which need to be strengthened. Since MTCT is assumed to be the main route of transmission in the Lao PDR, it is unsurprising that maternal infection was identified as risk factor in two studies $(23,24)$. Therefore, it is crucial to increase the coverage

344 of the hepatitis B birth dose in order to reduce the transmission of hepatitis B in the Lao PDR.

345 High infection rates represent a major public health challenge as treatment options in the 346 country are still limited. Only $18 \%$ of patients in a retrospective cohort study conducted in 2018 347 describing the treatment of HBV infections in Vientiane Capital were reported to receive 348 antiviral treatment (10).

349 Vaccination efforts will likely reduce the prevalence of chronic HBV in the Lao PDR in the 350 long run, even though it is difficult to produce generalizable data on vaccine coverage and vaccine-induced protection due to the geographic and ethnic heterogeneity (which may play an 
medRxiv preprint doi: https://doi.org/10.1101/2022.01.23.21265872; this version posted January $25,2022$. The copyright holder for this preprint (which was not certified by peer review) is the author/funder, who has granted medRxiv a license to display the preprint in It is made available under a CC-BY-NC-ND 4.0 International license.

352 important role) in the country (39). The aim of the World Health Organization - Western Pacific

353 Region was to reduce HBsAg-prevalence to less than $1 \%$ in children aged 5 years and increase

354 national coverage with both timely Hepatitis B birth dose (given within 24 hours of birth) and

355 the third Hepatitis B dose to $\geq 95 \%$ by 2017 (40). At the moment, national coverage rates are

356 at $55 \%$ and $85 \%$ for the birth dose and the third Hepatitis B dose, respectively (41). It is unlikely

357 that the target of reducing the HBsAg prevalence under $1 \%$ in children below 5 years is met in

358 the Lao PDR in the near future. To date, most of the data regarding the impact of vaccination

359 are derived from studies that did not randomly select participants or only report the prevalence

360 of HBsAg which hampers the possibility to extrapolate the data or to assess the levels of

361 vaccine-induced protection. One cross-sectional randomized study reported decreasing

362 exposure and infection rates after the introduction of HBV vaccination (32).

363 Despite the overall high prevalence of HBV infection in the Lao PDR, there are only two

364 studies focusing on risk groups. In 2013, a high proportion of Lao health care staff was found

365 to be susceptible to HBV and/or under-vaccinated (35). In addition, nearly half of the health

366 care staff showed evidence of past exposure to the virus (48.9\%). In the same year, a cross-

367 sectional survey among students of health care professions was carried out in Vientiane Capital

368 regarding their vaccination status, knowledge and awareness (42). Less than one third (21\%)

369 were fully vaccinated against HBV. When asked about the reason for not being vaccinated, the

370 most common answer was that they did not know where to get vaccinated. At present, there is

371 no national policy for the immunization or serological screening of health care workers, except

372 for influenza vaccination. A clear occupational health vaccination policy is needed to protect

373 health care workers and their patients and other at-risk populations. Furthermore, campaigns

374 promoting vaccination and raising awareness of the risks for health care providers and their

375 patients may prove beneficial. 
medRxiv preprint doi: https://doi.org/10.1101/2022.01.23.21265872; this version posted January $25,2022$. The copyright holder for this preprint (which was not certified by peer review) is the author/funder, who has granted medRxiv a license to display the preprint in It is made available under a CC-BY-NC-ND 4.0 International license.

376 In order to better protect potentially vulnerable populations, they must first be identified. Data

377 are needed regarding HBV infection among sex workers and men who have sex with men.

378 Furthermore, thalassemic and haemophilic patients and possible HBV co-infections with 379 dengue, malaria or HIV are not yet investigated. The ethnic diversity in the Lao PDR poses 380 another obstacle for the characterization of the HBV burden in the country. HBV infection rates among ethnic groups are not well described, apart from one study which took place in Saravan province(33) and could depend on local customs and risk practices such as tattooing, piercings, birth practices, sexual exposure etc.

384 The majority of the HBV strains characterized in the Lao PDR belonged to genotypes B and

385 C. The distribution of genotypes found may have implications for the public health responses in the country, as genotype $\mathrm{C}$ was reported to show higher rates of progression from cirrhosis to hepatocellular carcinoma as compared to genotype B or other genotypes and showed a lower response rate to interferon $(4,5)$.

389 In conclusion, Hepatitis B is still an important public health problem in the Lao PDR and more research is needed to better characterize its epidemiology. Interventions including HBV vaccination face many challenges but have showed first successes, at least in populations in central Lao PDR. In order to reduce the huge burden of HBV and its related morbidity and mortality in Lao PDR, such control measures need to be strengthened and sustained for the

394 foreseeable future. Furthermore, the management of the existing HBV burden needs to be improved through increased testing and treatment capacities.

\section{Limitations}

398 As a systematic review was performed, we did not include any existing grey literature on the 399 topic. Study identification and data extraction were performed by one investigator only, 
medRxiv preprint doi: https://doi.org/10.1101/2022.01.23.21265872; this version posted January $25,2022$. The copyright holder for this preprint (which was not certified by peer review) is the author/funder, who has granted medRxiv a license to display the preprint in It is made available under a CC-BY-NC-ND 4.0 International license .

400 possibly leading to selection bias. In addition, we cannot exclude the possibility that relevant

401 articles were missed because they are not indexed in the databases used for the literature search.

402 The heterogeneity of the studies concerning design, locations, methods and target population

403 hampered the comparability of the findings.

404

405 Author contributions

406 Lisa Hefele: Conceptualization; Data curation; Formal analysis; Methodology; Validation;

407 Visualization; Writing - original draft; Writing - review \& editing

408 Phonethipsavanh Nouanthong: Methodology; Validation; Writing - review \& editing

409 Judith M. Hübschen: Methodology; Validation; Writing - review \& editing

410 Claude P Muller: Supervision; Methodology; Validation; Writing - review \& editing

411 Antony P Black; Supervision; Methodology; Validation; Writing - original draft; Writing -

412 review \& editing 
medRxiv preprint doi: https://doi.org/10.1101/2022.01.23.21265872; this version posted January 25, 2022. The copyright holder for this preprint (which was not certified by peer review) is the author/funder, who has granted medRxiv a license to display the preprint in It is made available under a CC-BY-NC-ND 4.0 International license .

\section{References}

414 1. World Hepatitis Alliance. What is Viral Hepatitis?|World Hepatitis Alliance [Internet]. 2020 [cited 2020 Sep 28]. Available from: http://www.worldhepatitisalliance.org/what-viralhepatitis-0

417 2. World Health Organization. Global hepatitis report, 2017. 2017.

3. Coalition for Global Hepatitis Elimination. Interim Report: Progress towardsGlobal HBV and HCV Elimination [Internet]. 2020 [cited 2020 Oct 15]. Available from: https://www.globalhep.org/sites/default/files/content/resource/files/2020-07/Interim ReportProgress towards Global Hepatitis Elimination- WHD July 28 2020_0.pdf

4. Rajoriya N, Combet C, Zoulim F, Janssen HLA. How viral genetic variants and genotypes influence disease and treatment outcome of chronic hepatitis B. Time for an individualised approach? J Hepatol [Internet]. 2017;67(6):1281-97. Available from: https://doi.org/10.1016/j.jhep.2017.07.011

Revill PA, Tu T, Netter HJ, Yuen LKW, Locarnini SA, Littlejohn M. The evolution and clinical impact of hepatitis B virus genome diversity. Nat Rev Gastroenterol Hepatol. 2020;

6. Lin CL, Kao JH. Natural history of acute and chronic hepatitis B: The role of HBV genotypes and mutants. Best Pract Res Clin Gastroenterol [Internet]. 2017;31(3):249-55. Available from: http://dx.doi.org/10.1016/j.bpg.2017.04.010

7. Lunaček NK, Poljak M, Matičič M. Distribution of hepatitis B virus genotypes in europe and clinical implications: A review. Acta Dermatovenerologica Alpina, Pannonica Adriat. 2018;27(3):141-6.

8. Lin CL, Kao JH. Hepatitis B Virus Genotypes and Variants. Cold Spring Harb Perspect Med [Internet]. 2015 May;5(5):a021436-a021436. Available from: http://www.ncbi.nlm.nih.gov/pubmed/25934462

9. Sunbul M. Hepatitis B virus genotypes: global distribution and clinical importance. World J Gastroenterol [Internet]. 2014 May 14 [cited 2019 Aug 26];20(18):5427-34. Available from: http://www.ncbi.nlm.nih.gov/pubmed/24833873

10. Paboriboune P, Vial T, Chassagne F, Sitbounlang P, Soundala S, Bertani S, et al. A SevenYear Retrospective Study on the Surveillance of Hepatitis B in Laos. Int J Hepatol [Internet]. 2018 Apr;2018:1-11. Available from: https://www.hindawi.com/journals/ijh/2018/9462475/

11. World Health Organization, United Nations Children's Fund. Lao People's Democratic

Republic: WHO and UNICEF estimates of immunization coverage: 2018 revision. 2019.

12. Black AP, Nouanthong P, Nanthavong N, Souvannaso C, Vilivong K, Jutavijittum P, et al. Hepatitis B virus in the Lao People's Democratic Republic: a cross sectional serosurvey in different cohorts. BMC Infect Dis [Internet]. 2014 Dec 23 [cited 2018 May 24];14(1):457. Available from: http://www.ncbi.nlm.nih.gov/pubmed/25149478

13. Phoummalaysith B, Yamamoto E, Xeuatvongsa A, Louangpradith V, Keohavong B, Saw YM, et al. Factors associated with routine immunization coverage of children under one year old in Lao People's Democratic Republic. Vaccine [Internet]. 2018 May 3 [cited 2018 May 24];36(19):2666-72. Available from: http://www.ncbi.nlm.nih.gov/pubmed/29606518

14. World Health Organization. Hepatitis B - Factsheet [Internet]. 2020 [cited 2019 May 8]. 
medRxiv preprint doi: https://doi.org/10.1101/2022.01.23.21265872; this version posted January 25, 2022. The copyright holder for this preprint (which was not certified by peer review) is the author/funder, who has granted medRxiv a license to display the preprint in It is made available under a CC-BY-NC-ND 4.0 International license .

bars $\mathrm{v}=2018 \&$ mode $=$ population $\&$ mode_population $=$ countries $\&$ population $=900 \&$ populations $=900 \& \mathrm{key}=$ asr $\&$ se $x=0 \&$ cancer $=11 \&$ type $=0 \&$ statistic $=5 \&$ prevalence $=0 \&$ population_group $=0$ \&ages_group $\% 5 \mathrm{~B} \% 5 \mathrm{D}=0 \&$ ages_group $\% 5 \mathrm{~B} \% 5 \mathrm{D}=17 \& \mathrm{nb} \_$items

16. Moher D, Liberati A, Tetzlaff J, Altman DG, PRISMA Group TP. Preferred reporting items for systematic reviews and meta-analyses: the PRISMA statement. PLoS Med [Internet]. 2009 Jul 21 [cited 2019 Aug 26];6(7):e1000097. Available from: http://www.ncbi.nlm.nih.gov/pubmed/19621072

17. Olinger CM, Jutavijittum P, Hubschen JM, Yousukh A, Samountry B, Thammavong T, et al. Possible new hepatitis B virus genotype, southeast Asia. Emerg Infect Dis [Internet]. 2008;14(11):1777-80. Available from: http://www.ncbi.nlm.nih.gov/pubmed/18976569

18. Andernach IE, Jutavijittum P, Samountry B, Yousukh A, Thammavong T, Hubschen JM, et al. A high variability of mixed infections and recent recombinations of hepatitis B virus in Laos. PLoS One [Internet]. 2012;7(2):e30245. Available from: http://www.ncbi.nlm.nih.gov/pubmed/22383959

19. Jutavijittum P, Andernach IE, Yousukh A, Samountry B, Samountry K, Thammavong T, et al. Occult hepatitis B infections among blood donors in Lao PDR. Vox Sang [Internet]. 2014;106(1):31-7. Available from: http://www.ncbi.nlm.nih.gov/pubmed/23931585

20. Jutavijittum P, Yousukh A, Samountry B, Samountry K, Ounavong A, Thammavong T, et al. Seroprevalence of hepatitis B and C virus infections among Lao blood donors. Southeast Asian J Trop Med Public Health [Internet]. 2007 Jul;38(4):674-9. Available from: http://www.ncbi.nlm.nih.gov/pubmed/17883005

21. Syhavong B, Rasachack B, Smythe L, Rolain JM, Roque-Afonso AM, Jenjaroen K, et al. The infective causes of hepatitis and jaundice amongst hospitalised patients in Vientiane, Laos. Trans R Soc Trop Med Hyg [Internet]. 2010;104(7):475-83. Available from: http://dx.doi.org/10.1016/j.trstmh.2010.03.002

22. Bounlu K, Insisiengmay S, Vanthanouvong K, Saykham, Widjaja S, Iinuma K, et al. Acute Jaundice in Vientiane, Lao People's Democratic Republic. 2016;8-13.

23. Xeuatvongsa A, Komada K, Kitamura T, Vongphrachanh P, Pathammavong C, Phounphenghak K, et al. Chronic hepatitis B prevalence among children and mothers: results from a nationwide, population-based survey in Lao People's Democratic Republic. PLoS One [Internet]. 2014;9(2):e88829. Available from: http://www.ncbi.nlm.nih.gov/pubmed/24586408

24. Komada K, Sugiyama M, Vongphrachanh P, Xeuatvongsa A, Khamphaphongphane B, Kitamura T, et al. Seroprevalence of chronic hepatitis B, as determined from dried blood spots, among children and their mothers in central Lao People's Democratic Republic: a multistage, stratified cluster sampling survey. Int J Infect Dis [Internet]. 2015;36:21-6. Available from: http://www.ncbi.nlm.nih.gov/pubmed/25957815

25. Jutavijittum P, Yousukh A, Saysanasongkham B, Samountry B, Samountry K, Toriyama K, et al. High Rate of Hepatitis B Virus Mother-to-Child Transmission in Lao People's Democratic Republic. Southeast Asian J Trop Med Public Heal [Internet]. 2016;47(2):214-8. Available from: http://www.ncbi.nlm.nih.gov/pubmed/27244958

26. Xaydalasouk K, Keomalaphet S, Latthaphasavang V, Souvong V, Buisson Y. Évaluation du risque de transmission materno-fœtale du virus de l'hépatite $\mathrm{B}$ en consultation prénatale à Vientiane, Laos. Bull la Société Pathol Exot [Internet]. 2016 Feb;109(1):13-9. Available from: http://link.springer.com/10.1007/s13149-016-0474-5

27. Choisy M, Keomalaphet S, Xaydalasouk K, Quet F, Latthaphasavang V, Buisson Y. Prevalence of Hepatitis B Virus Infection among Pregnant Women Attending Antenatal Clinics in Vientiane, Laos, 2008-2014. Hepat Res Treat [Internet]. 2017;2017:1284273. 
medRxiv preprint doi: https://doi.org/10.1101/2022.01.23.21265872; this version posted January 25, 2022. The copyright holder for this preprint (which was not certified by peer review) is the author/funder, who has granted medRxiv a license to display the preprint in It is made available under a CC-BY-NC-ND 4.0 International license .

28. Evdokimov K, Sayasinh K, Nouanthong P, Vilivong K, Samountry B, Phonekeo D, et al. Low and disparate seroprotection after pentavalent childhood vaccination in the Lao People's Democratic Republic: a cross-sectional study. Clin Microbiol Infect [Internet]. 2017;23(3):197-202. Available from: http://dx.doi.org/10.1016/j.cmi.2016.10.007

29. Hefele L, Syphan S, Xayavong D, Homsana A, Kleine D, Chanthavilay P, et al. Seroprotection at Different Levels of the Healthcare System After Routine Vaccination With DiphtheriaDemocratic Republic. Clin Infect Dis [Internet]. 2019 Feb 19 [cited 2019 May 8]; Available from: https://academic.oup.com/cid/advance-article/doi/10.1093/cid/ciz143/5335760

30. Latthaphasavang V, Vanhems P, Ngo-Giang-Huong N, Sibounlang P, Paboriboune P, Malato $\mathrm{L}$, et al. Perinatal hepatitis B virus transmission in Lao PDR: A prospective cohort study. PLoS One. 2019;14(4):1-14.

31. Norizuki M, Kitamura T, Komada K, Sugiyama M, Mizokami M, Xeuatvongsa A, et al. Serologic testing of randomly selected children after hepatitis B vaccination: A cross-sectional population-based study in Lao People's Democratic Republic. BMC Infect Dis. 2019;19(1):19.

32. Hefele L, Vannachone S, Khounvisith V, Phonethipsavanh N, Sayasone S, Kounnavong S, et al. Lasting benefit of infant hepatitis B vaccination in adolescents in the Lao People's Democratic Republic. Int J Infect Dis [Internet]. 2020 [cited 2021 Apr 14];93:217-23. Available from: https://linkinghub.elsevier.com/retrieve/pii/S1201971220300588

33. Xaydalasouk K, Sayasinh K, Hübschen JM, Khounvisith V, Keomany S, Muller CP, et al. Age-stratified seroprevalence of vaccine-preventable infectious disease in Saravan, Southern Lao People's Democratic Republic. Int J Infect Dis. In press.

34. Xaydalasouk K, Strobel M, Buisson Y, Black AP, Muller CP. Seroprevalence and risk factors of hepatitis $\mathrm{B}$ and $\mathrm{C}$ virus infections in female workers of Lao garment factories. Khudyakov YE, editor. PLoS One [Internet]. 2018 Jul 16 [cited 2021 Apr 14];13(7):4-11. Available from: https://dx.plos.org/10.1371/journal.pone.0199919

35. Black AP, Vilivong K, Nouanthong P, Souvannaso C, Hübschen JM, Muller CP.

Serosurveillance of vaccine preventable diseases and hepatitis $\mathrm{C}$ in healthcare workers from Lao PDR. Borrow R, editor. PLoS One [Internet]. 2015 Apr 14 [cited 2019 May 28];10(4):111. Available from: http://www.ncbi.nlm.nih.gov/pubmed/25874696

36. Mangkara B, Xaydalasouk K, Chanthavilay P, Kounnavong S, Sayasone S, Muller CP, et al. Hepatitis B virus in Lao dentists: A cross-sectional serological study. Ann Hepatol [Internet]. 2021 May 1 [cited 2021 Mar 19];22. Available from: http://www.elsevier.es/en-revista-annalshepatology-16-avance-resumen-hepatitis-b-virus-in-lao-S1665268120302076

37. Olsen SJ, Vetsaphong P, Vonglokham P, Mirza S, Khanthamaly V, Chanthalangsy T, et al. A retrospective review of birth outcomes at the Mother and Child Health Hospital in Lao People's Democratic Republic, 2004-2013. BMC Pregnancy Childbirth [Internet]. 2016;16(1):379. Available from: http://www.ncbi.nlm.nih.gov/pubmed/27894346

38. Shepard CW, Simard EP, Finelli L, Fiore AE, Bell BP. Hepatitis B virus infection: 39. Lao Statistics Bureau. Lao Social Indicator Survey II 2017, Survey Findings Report. Epidemiology and vaccination. Epidemiol Rev. 2006;28(1):112-25.

40. Woodring J, Pastore R, Brink A, Ishikawa N, Takashima Y, Tohme RA. Progress toward hepatitis B control and elimination of mother-to-child transmission of hepatitis B virus - 
medRxiv preprint doi: https://doi.org/10.1101/2022.01.23.21265872; this version posted January $25,2022$. The copyright holder for this preprint (which was not certified by peer review) is the author/funder, who has granted medRxiv a license to display the preprint in It is made available under a CC-BY-NC-ND 4.0 International license .

Western Pacific Region, 2005-2017. Morb Mortal Wkly Rep. 2019;68(8):195-200.

551

41. World Health Organization, United Nations Children's Fund. Lao People's Democratic

42. Pathoumthong K, Khampanisong P, Quet F, Latthaphasavang V, Souvong V, Buisson Y. Republic: WHO and UNICEF estimates of immunization coverage: 2017 revision. 2018. Vaccination status, knowledge and awareness towards hepatitis B among students of health professions in Vientiane, Lao PDR. Vaccine [Internet]. 2014 Sep;32(39):4993-9. Available from: http://www.ncbi.nlm.nih.gov/pubmed/25066734 